\title{
Exploring the Difference between Stayers and Switchers as Corporate Customers for Life Insurance Companies in Sindh
}

\author{
Falah-ud-Din Butt ${ }^{1}$, Niaz Ahmed Bhutto ${ }^{1} \&$ Minhoon Khan Laghari ${ }^{2}$ \\ ${ }^{1}$ Department of Business Administration, Sukkur Institute of Business Administration, Sindh, Pakistan \\ ${ }^{2}$ Department of Business Administration, Shah Abdul Latif University Khairpur, Sindh, Pakistan \\ Correspondence: Minhoon Khan Laghari, Department of Business Administration, Shah Abdul Latif University \\ Khairpur, Sindh, Pakistan. E-mail: lagharimk@hotmail.com
}

Received: November 1, 2011

Accepted: December 9, $2011 \quad$ Published: May 1, 2012

doi:10.5539/ass.v8n6p233

URL: http://dx.doi.org/10.5539/ass.v8n6p233

\begin{abstract}
Purpose - Competitiveness plays crucial role retaining the old customers. This lays importance on understanding the factors that influence and drive customers' retention. Basing on the above, the Purpose of this paper to investigate and examine whether the Stayers, Satisfied Switchers, and Dissatisfied Switchers of corporate customers differ in their overall satisfaction with the service provided by their existing/current life insurance company.

Methodology - This study has used survey via questionnaires for data collection. 75 corporate customers on the basis of convenience sampling were examined by using ANOVA and Discriminant Analysis techniques.

Findings - The results show that Dissatisfied Switchers (who switched -in) are the most satisfied, and Satisfied Switchers are the least satisfied customers. Similar sort of results were found for customer's loyalty. These three groups were found to be strongly discriminated by the people factor (specifically the professional insurance employees).

Research limitations - The data is gathered from some big cities of Sindh through convenience sampling technique. There are many other cities where access of information is not possible due to cost and time management. Further research can be made on the same just by extending the sample size by considering more cities of Sindh.

Practical implications - As the findings of this study reveal that the Dissatisfied Switchers are of the primary concern for life insurance companies. Keeping in view the results the life insurance companies should treat these groups differently with regard to potential investment strategy.
\end{abstract}

Originality/value - This study has not been done before in Sindh. Although some studies are found in European countries but this has been done first time in Sindh and Pakistan.

Keywords: stayers \& switchers, life insurance companies, Sindh

\section{Introduction}

Modern dynamic economies have created many new challenges and opportunities for the firms. The most important point is that the modern economies assuredly place the customer more firmly in the driver's seat for decisions on her/his product and service choices (customization and customerization). Each consumer either as an individual or as a group is unique and this uniqueness is reflected in the consumption pattern and process of purchase. The study of consumer behavior provides us with reasons why consumers differ from one another in consuming products and services. The satisfaction of buyers' needs is at the heart of a market economy, and is the core theme of marketing.

Customers view a product as a 'bundle of satisfaction' and not merely the physical object, and give importance to both the tangible and intangible attributes of a product. Intangibles provide psychological and social benefits for the buyer. If product attributes don't benefit a customer, they have no significance for them. Today's customers are becoming harder to please. They are smarter, more price conscious, more demanding, less forgiving, and they are approached by many more competitors with equal or better offers. Therefore the real challenge is to produce delighted and loyal customers. For that purpose should all the customers be targeted by retention and loyalty programs or not, and what is the guarantee that the delighted and loyal customer will not switch due to a reason that might be uncontrollable for both the firm and the customer itself. 
It is interesting to note that no two customers are exactly alike; customer differs on many dimensions, such as intelligence, personality, interests, hobbies, opinions, and preferences. In a similar manner firms (corporate customers) are different in their nature and have different need for insurance policies. If the Life Insurance Companies are really interested in comprehending the customer insight for more appropriate customer acquisition and retention strategies, it is important to understand the difference between different groups of corporate customers on the basis of behavior (SBP, 2005).

Like many other industries, the life insurance business was nationalized in the early 1970s, In the early 1990s the life business was deregulated and today four private life insurance companies, two local and two foreign are competing with the state-owned State Life Insurance Corporation which enjoys an envious edge made possible primarily due to the monopoly it enjoyed for almost two decades. Therefore, as the corporate customer the options for different companies operating in Pakistan are very few keeping in view the small number of life insurance companies in Pakistan.

\subsection{Objectives}

The main objectives of the study are:

To examine whether the three groups (Stayers, Satisfied Switchers, and Dissatisfied Switchers) of corporate customers differ in their overall satisfaction with the service provided by their existing/current life insurance company.

To investigate the role of satisfaction with the various attributes of the service in differentiating among the groups

To examine whether the three groups namely; Stayers, Satisfied Switchers, and Dissatisfied Switchers, differ in their loyalty behavior toward the service

\subsection{Problem Statements}

To find the difference between Stayers and Switchers as corporate customers in relation to satisfaction and loyalty towards the service provided by the existing/current life insurance company in Pakistan.

\subsection{Research Questions}

i) Whether the Dissatisfied Switchers are more satisfied than Stayers and Satisfied Switchers or not?

ii) Whether the Stayers are more satisfied than Satisfied Switchers or not?

iii) Whether the three groups can strongly be discriminated on the basis of their satisfaction with the professionalism factor?

iv) Whether the Dissatisfied Switchers are more loyal than the Stayers and Satisfied Switchers?

v) Whether the Stayers are more loyal than the Satisfied Switchers?

\section{Review of Literature}

Researches about customer groups such as 'stayers' and 'switchers' has been limited to date. Only a few studies (East et al. 2001; Ganesh et al., 2000; Mittal and Katrichis, 2000) compare new customer and long-term customer groups. In light of mature markets and increasing competitive pressure, retaining the existing customer base becomes crucial for the future success of a firm (Boehm, 2008). As a consequence, firms are increasingly interested in understanding the factors influencing and driving customer retention. As this switching and staying behavior of the customer is strongly related with the satisfaction or dissatisfaction of the customers and according to confirmation/disconfirmation paradigm, customer satisfaction can be described as the outcome of a comparison process between perceived product performance and previously held expectations. When performance exceeds expectations, positive disconfirmation occurs and leads to satisfaction, while performance below expectations results in negative disconfirmation and dissatisfaction (Oliver, 1997).

A number of studies studies have shown that switchers base their satisfaction judgments on different factors than stayers (Mittal and Katrichis, 2000), that overall satisfaction and loyalty differ among the two groups (Ganesh et al., 2000) and that satisfaction has a stronger effect on the duration of the customer relationship for long-term customers than for recent recruits (Bolton, 1998). Wangenheim and Bayon (2004) argued that referral switchers differ from other switchers and represent a highly valuable customer group for a service provider. A study of Deirdre and Isabelle (2006) provides a review of the current relationship marketing and loyalty building literatures and investigates current consumer perspectives on the role of relationships, the nature of loyalty and types of customer interaction within Irish retail banking.

The level of expectation held is greatly influenced by recent experiences with the product or service organizations (LaTour and Peat, 1980). The outcomes below expectations should result in switchers entering a new relationship with lower comparison standards and the stayers, in comparison, should not hold reduced expectation levels because they have not experienced such negative differences between expectations and 
performance (Mazursky et al., 1987). The loyalty of the customers is multidimensional and includes not only repeat buying behavior, but also other aspects that are geared towards the support of a provider, such as repurchasing or resistance towards price increases (Dick and Basu, 1994).

It has been argued that Relationship Marketing (RM) is not suitable for all consumer markets, there appears majority of the opinion in the literature that a relationship strategy is suitable for most services (Dall'Olmo Riley and De Chernatony, 2000) including retail banking and financial services (Bejou et al., 1998; Colgate and Stewart, 1998). Research in relationship marketing has for some time now argued that creating and developing relationships contributes to the success of firms (Morgan \& Hunt, 1994). Some authors explain that firms can even use relationship marketing as a competitive advantage (Day, 2000).

Through effective relationship marketing organizations can fulfill as the desire to develop and carry on long-term exchange relationships, a desire that materializes in the realization of implicit and explicit promises, as well as sacrifices in favor of the economic and social well-being of all the parties having some interest in the relationship (Anderson \& Weitz, 1992; Dwyer, Schurr, \& Oh, 1987; Morgan \& Hunt, 1994; Walter \& Ritter, 2000).

\section{Research Methodology}

\subsection{The Variables}

The selection of potentially relevant variables is based on the prior research studies, consultation with life insurance company's executives, and discussion with corporate customers.

The following variables are identified that may affect the satisfaction level and loyalty behavior of corporate customers:

\subsubsection{Customer Satisfaction}

i) Professionalism: Acquired development, level of training, competencies and level of expertise of the insurance employees can influence the customer' satisfaction level.

ii) Prompt Payments: Readiness with which the claims are paid to the customers.

iii) Premium: the amount of money charged annually against the policies from the customers.

iv) Commission: Discounts specifically, given to the corporate customers against the premiums.

\subsubsection{Customer Loyalty}

v) Recommendation: Enticing and referring company name to others.

vi) Future Intention to Switch: Planning to change the existing company (to whom they are currently buying policy) in future.

vii) Raised Prices: Higher amount of premium than regular.

viii) Competitive Rates: Premium charged, commission paid, or better services offered by the other competing firm.

\subsection{Data Collection}

For this study data was collected through personally administrated questionnaire based on four questions for each of both the customer satisfaction and customer loyalty, and one regarding the over all satisfaction.

Based on quantitative nature of this research study, both the Descriptive as well as Analytical approaches in which the quantitative tools: ANOVA and Discriminant Analysis are used to analyze the data. Through convenience sampling, seventy five (75) corporate customers were visited in Sindh (province). Corporate customers were approached by getting an appointment on telephone from the Finance Director/Manager or Accounts Officer of different companies, who usually finalize the deal with the insurance companies.

\subsection{Hypothesis}

On the basis of literature review five hypotheses were formulated.

H1: Dissatisfied Switchers are more satisfied with their current life insurance company (CLIC) in comparison to Satisfied Switchers and Stayers.

H2: Satisfied Switchers are less satisfied with their current life insurance company in comparison to Stayers.

H3: Satisfaction with the people factor of the service is stronger Discriminant of the three groups of customers than satisfaction with the other aspects of the service.

H4: Dissatisfied Switchers are more loyal to their current life insurance company in comparison to both Satisfied Switchers and Stayers.

H5: Satisfied Switchers are less loyal to their current life insurance company in comparison to Stayers. 


\section{Data Analysis and Results}

To test these hypotheses, grouped means were compared on the overall satisfaction item, using analysis of variance (ANOVA). The results (see Table1) reveal that the groups differ significantly in their overall satisfaction with their CLIC. Furthermore, the results shows that the Dissatisfied Switchers (mean score $=4.52)$ are significantly more satisfied with their CLIC than the other two groups and that the Satisfied Switchers (mean score $=3.92)$ are significantly less satisfied than the Stayers (mean score $=4.24)$. This provides support for hypotheses $\mathrm{H} 1$ and $\mathrm{H} 2$. The researcher can accept the two hypotheses $\mathrm{H} 1$ and $\mathrm{H} 2$ very strongly as the difference between groups are significant at the $\mathrm{p}=0.05$ level.

Table 1. Overall satisfaction measure: difference between group means

\begin{tabular}{|c|c|c|c|}
\hline Measure & Groups & $\begin{array}{l}\text { Mean } \\
\text { Scores }\end{array}$ & Difference b/w Means* \\
\hline \multirow{3}{*}{$\begin{array}{l}\text { Overall, how } \\
\text { much satisfied } \\
\text { your firm is } \\
\text { with the } \\
\text { current life } \\
\text { insurance } \\
\text { company? }\end{array}$} & $\begin{array}{l}\text { Stayers } \\
(\mathrm{n}=25)\end{array}$ & 4.2400 & $\begin{array}{l}\text { Stayers versus Satisfied Switchers } \\
\mathbf{0 . 3 2 0 0}\end{array}$ \\
\hline & $\begin{array}{l}\text { Satisfied Switchers } \\
(\mathrm{n}=25)\end{array}$ & 3.9200 & $\begin{array}{l}\text { Stayers versus Dissatisfied Switchers } \\
-\mathbf{0 . 2 8 0 0}\end{array}$ \\
\hline & $\begin{array}{l}\text { Dissatisfied Switchers } \\
(\mathrm{n}=25)\end{array}$ & 4.5200 & $\begin{array}{l}\text { Satisfied Switchers versus Dissatisfied } \\
\text { Switchers } \\
\mathbf{- 0 . 6 0 0 0}\end{array}$ \\
\hline
\end{tabular}

* The difference between group means, significant at the $\mathrm{p}=0.05$ level

The significance attached to the Univariate $F$ ratios (see Table 2) indicates that when the predictors are considered individually, only professionalism is significant in differentiating between the three groups, but premium, price and competitive rates also have a reasonable ratio to differentiating three groups in comparison to the rest of the variables.

Table 2. Wilkas' $\lambda$ (U-statistic) and Univariate $F$ ratio with 2 and 72 degrees of freedom

\begin{tabular}{llllll}
\hline & Wilks' Lambda & F & df1 & df2 & Sig. \\
\hline Profess. & .659 & 18.592 & 2 & 72 & .000 \\
Pmpt.Pmt & .924 & 2.975 & 2 & 72 & .057 \\
Premium & .859 & 5.919 & 2 & 72 & .004 \\
Comm & .961 & 1.474 & 2 & 72 & .236 \\
Recomd & .975 & .925 & 2 & 72 & .401 \\
F. Switch & .957 & 1.625 & 2 & 72 & .204 \\
Price & .855 & 6.123 & 2 & 72 & .004 \\
C. Rates & .860 & 5.860 & 2 & 72 & .004 \\
\hline
\end{tabular}

Because there are three groups, a maximum of two functions can be extracted. The Eigenvalue associated (see Table 3) with the first function is 0.904 , and this function accounts for $96.90 \%$ of the explained variance. Because the Eigenvalue of the Function 1 is large in comparison to the Function 2, that is only 0.29 and accounts for only $3.10 \%$ of the explained variance, The Function 1 is likely to be superior.

Table 3. Eigen values

\begin{tabular}{lllll}
\hline Function & Eigen value & \% of Variance & Cumulativ \% & $\begin{array}{l}\text { Canonical } \\
\text { Correlation }\end{array}$ \\
\hline 1 & $.904 \mathrm{a}$ & 96.9 & 96.9 & .689 \\
2 & $.029 \mathrm{a}$ & 3.1 & 100.0 & .167 \\
\hline
\end{tabular}

The value of Wilks' $\lambda$ (see Table 4 ) is 0.511 . This transforms to a Chi-square of 46.038 , with 16 degrees of freedom, which is significant beyond the 0.05 level. Thus the two functions together significantly discriminate among the three groups. However, when the Function 1 is removed, the Wilks' $\lambda$ associated with Function 2 is 0.972 , which is not significant at the 0.05 level. 
Table 4. Wilks' lambda

\begin{tabular}{lllll}
\hline Test of Function(s) & Wilks' Lambda & Chi-square & df & Sig. \\
\hline 1 through 2 & .511 & 46.038 & 16 & .000 \\
2 & .972 & 1.939 & 7 & .963 \\
\hline
\end{tabular}

The Standardized discriminant function coefficients (see Table 5) indicate large coefficients for professionalism, competitive rates, and price on Function 1, where as Function 2 has relatively larger coefficients for prompt payments and future intention to switch. A similar conclusion is reached by an examination of the Structure matrix (see Table 6).

Table 5. Standardized canonical discriminant function coefficients

\begin{tabular}{lcc}
\hline & Function 1 & Function 2 \\
\hline Profess. & .899 & .064 \\
Pmpt.Pmt & -.343 & .573 \\
& & \\
Premium & .211 & .226 \\
Comm & -.058 & .287 \\
Recomd & -.169 & -.268 \\
F. Switch & -.131 & .624 \\
Price & .437 & -.321 \\
C. Rates & .507 & -.748 \\
\hline
\end{tabular}

Table 6. Structural matrix

\begin{tabular}{lcc}
\hline & Function & Function \\
& $\mathbf{1}$ & $\mathbf{2}$ \\
\hline Profess. & $.752^{*}$ & .449 \\
Price & $.434^{*}$ & -.036 \\
Premium & $.425^{*}$ & .190 \\
C. Rates & $.419^{*}$ & -.375 \\
Recomd & $.168^{*}$ & .088 \\
F. Switch & .204 & $.509^{*}$ \\
Comm & .199 & $.427^{*}$ \\
Pmpt.Pmt & .295 & $.383^{*}$ \\
\hline
\end{tabular}

To help interpret the functions, variables with large coefficients for a particular function are grouped together. These groupings are shown with asterisks. Thus, professionalism, price, premium, competitive rates, and recommendation have asterisks for Function 1, because these variables have coefficients that are larger for Function 1 than Function 2. On the other hand future intention to switch, commission, and prompt payments are predominantly associated with Function 2, as indicated by asterisks.

\section{Findings}

The research provides a much needed perspective on customers who switched-in and how they differ from Stayers in terms of satisfaction and loyalty. Five different hypotheses were developed and tested, and all are accepted and discussed below: 
Hypotheses 1 and 2 were tested using analysis of variance and the results shows that the Dissatisfied Switchers are more satisfied (mean score $=4.52$ ) than the other two groups and the Satisfied Switchers (mean score $=3.92)$ are significantly less satisfied than the Stayers (mean score $=4.24$ ). Hypotheses 1 and 2 are accepted very strongly as the difference between groups are significant at the $\mathrm{p}=0.05$ level.

The standard canonical discriminant function coefficient indicates large coefficients for professionalism, competitive rates and price on F1. Where as F2 have relatively larger coefficients for prompt events and future intentions to switch.

The professionalism (people factor) is prominent with having a largest ratio of 0.899 which is significant enough in discriminating the 3 groups then the other 7 factors. The groups mean scores for professionalism also support the hypothesis 3 as the mean score decreases from, 4.52 to 4.08 to 3.52 for Dissatisfied Switchers, Stayers, and Satisfied Switchers.

The standard canonical discriminant function coefficient indicates large coefficients for professionalism, competitive rates and price on F1. Where as F2 have relatively larger coefficients for prompt events and future intentions to switch.

The professionalism (people factor) is prominent with having a largest ratio of 0.899 which is significant enough in discriminating the 3 groups then the other 7 factors. The groups mean scores for professionalism also support the hypothesis 3 as the mean score decreases from, 4.52 to 4.08 to 3.52 for Dissatisfied Switchers, Stayers, and Satisfied Switchers.

\section{Conclusion and Recommendations}

The results of the study confirms the all the five hypotheses that reveals that the Dissatisfied Switchers are of the primary concern for life insurance companies. Dissatisfied Switchers are relatively at the top in terms of their overall satisfaction with the existing/current life insurance company. Where as Satisfied Switchers are the least satisfied on the same scale.

Out of the eight variables under study, professionalism is the variable that strongly discriminating the three groups. So far as the loyalty behavior is concern, again Dissatisfied Switchers are exhibiting stronger commitment than Stayers and Satisfied Switchers.

Keeping in view the results the authors suggest that the life insurance companies should treat these groups differently with regard to potential investment strategy. Dissatisfied switchers and Stayers have the potential to provide differential value above and beyond mere repeat patronage so insurance companies should capitalize on this particular aspect for reaping better results.

Corporate customer's satisfaction heavily depends upon the professionalism of the life insurance employees. If these highly trained and professional employees will listen carefully to the needs of their customers then there in no doubt that they will be able to win the trust of them. Specifically in service sector where companies don't have any tangible product to offer, they can only win their customers by winning their hearts.

Front line employees, the eyes and the ears of the company need more attention. Authors strongly suggest that Insurance companies should invest more in the human resource for training and development of employees. These employees are the ambassador having a direct contact with the corporate customers, and in this era of competition a minor mistake can spoil the whole curry.

Life insurance companies should avoid over investment and heavy dependency on satisfied switchers, as they are at the bottom of overall satisfaction level in comparison to Dissatisfied Switchers, and Stayers. Whenever company will think to raise prices they will be the first to switch, or whenever they get better rates they will be the first to switch.

\section{References}

Anderson, E., \& Weitz, B. (1992). The use of pledges to built and sustains commitment in distribution channels. Journal of Marketing Research, 29, 18-34. http://dx.doi.org/10.2307/3172490

BejouD, Ennew C., \& Palmer A. (1998). Trust, ethics and relationship satisfaction. International Journal of Bank Marketing, 16(4), 170-175. http://dx.doi.org/10.1108/02652329810220729

Boehm M. (2008). Determining the impact of Internet channel use on a customer's lifetime. Journal of Interactive Marketing, 22(3), 2-22. http://dx.doi.org/10.1002/dir.20114

Bolton, R. N. (1998). A dynamic model of the duration of the customer's relationship with a continuous service provider: The role of satisfaction. Marketing Science, 17, 45-65. http://dx.doi.org/10.1287/mksc.17.1.45 
Dall'Olmo Riley F., \& de Chernatony L. (2000). The service brand as relationship builder. British Journal of Management, 11(2), 137-150. http://dx.doi.org/10.1111/1467-8551.t01-1-00156

Day, G. S. (2000). Managing market relationships. Journal of the Academy of Marketing Science, 28, 24-30. http://dx.doi.org/10.1177/0092070300281003

Dick, A. S., \& Basu, K. (1994). Customer loyalty: Toward an integrated conceptual framework. Journal of the Academy of Marketing Science, 22, 99-113. http://dx.doi.org/10.1177/0092070394222001

Dwyer, R., Schurr, P., \& Oh, S. (1987). Developing buyer-seller relationships. Journal of Marketing, 51, 11-27. http://dx.doi.org/10.2307/1251126

East, R., Lomax, W., \& Narain, R. (2001). Customer tenure, recommendation and switching. Journal of Consumer Satisfaction, Dissatisfaction and Complaining Behavior, 14, 46-54.

Ennew C., \& Binks M. (1996). The impact of service quality and service characteristics on customer retention: small businesses and their banks in the UK. British Journal of Management, 7(3), 219-230. http://dx.doi.org/10.1111/j.1467-8551.1996.tb00116.x

Ganesh, J., Arnold, M. J., \& Reynolds, K. E. (2000). Understanding the customer base of service providers: An examination of the differences between switchers and stayers. Journal of Marketing, 64, 65-87. http://dx.doi.org/10.1509/jmkg.64.3.65.18028

LaTour, S. A., \& Peat, N. C. (1980). The role of situationally produced expectations, others' experiences and prior experience in determining consumer satisfaction. In Olson, J. C. (Ed.), Advances in Consumer Research. Association for Consumer Research, Ann Arbor, MI.

Mazursky, D., LaBarbera, P., \& Aielly, A. (1987). When consumers switch brands. Psychology and Marketing, 4, 17-30. http://dx.doi.org/10.1002/mar.4220040104

Mittal, V., \& Katrichis, J. M. (2000). Distinctions between new and loyal customers. Marketing Research, Spring, 26-32.

Morgan, R., \& Hunt, S. (1994). The commitment-trust theory of the relationship marketing. Journal of Marketing, 58, 20-38. http://dx.doi.org/10.2307/1252308

O'Loughlin, D., \& Szmigin, I. (2006). Emerging perspectives on customer relationships, interactions and loyalty in Irish retail financial services. Journal of Consumer Behaviour, 5, 117-129. http://dx.doi.org/10.1002/cb.39

Oliver, R. L. (1997). Satisfaction: A Behavioral Perspective on the Consumer. Irwin/McGraw-Hill, Boston, MA.

State Bank of Pakistan. (2005). Pakistan Financial Sector Assessment 2005. Retrieved from http://www.sbp.org.pk/publications/FSA/2005/index.htm

Walter, A., \& Ritter,T. (2000). Value-creation on customer-supplier relationship: The role of adaptation, trust and commitment. $29^{\mathrm{a}}$ EMAC Conference, Rotterdam.

Wangenheim F., \& Bayon T. (2004). Satisfaction, loyalty and word of mouth within the customer base of a utility provider: differences between stayers, switchers and referral switchers. Journal of Consumer Behavior, 3(3), 211-220. http://dx.doi.org/10.1002/cb.135 